Narrative Works

Issues, Investigations, \& Interventions

\title{
Narrating Selves Create Memories
}

\section{Arthur W. Frank}

Volume 8, Number 1-2, 2018

URI: https://id.erudit.org/iderudit/1059853ar

DOI: https://doi.org/10.7202/1059853ar

See table of contents

Publisher(s)

Centre for Interdisciplinary Research on Narrative, St. Thomas University

\section{ISSN}

1925-0622 (digital)

Explore this journal

Cite this review

Frank, A. (2018). Review of [Narrating Selves Create Memories]. Narrative Works, 8(1-2). https://doi.org/10.7202/1059853ar viewed online.

https://apropos.erudit.org/en/users/policy-on-use/ 


\title{
NARRATIVE WORKS
}

Issues, Investigations, \& Interventions

\section{BOOK REVIEW}

\section{Narrating Selves Create Memories}

\author{
Arthur W. Frank \\ University of Calgary \& VID Specialized University, Oslo
}

Jens Brockmeier. Beyond the Archive: Memory, Narrative, and the Autobiographical Process. New York, NY: Oxford University Press, 2015. Hardcover. ISBN: 978-0-19-986156-9.

Lars-Christer Hydén. Entangled Narratives: Collaborative Storytelling and the Re-Imagining of Dementia. New York: Oxford University Press, 2018. Hardcover. ISBN: 978-0-19-939157-8.

William L. Randall. The Narrative Complexity of Ordinary Life: Tales from the Coffee Shop. New York: Oxford University Press, 2015. Paperback. ISBN: 978-0-19-067513-4.

Brian Schiff, A. Elizabeth McKim, and Sylvia Patron, editors. Life as Narrative: The Risks and Responsibilities of Storying Experience. New York: Oxford University Press, 2017. Hardcover. ISBN: 978-0-19025665-4.

The accumulated weight of these four volumes-about 1150 pages - attests the depth of academic interest in narrative. The authors have multiple disciplinary backgrounds and present different kinds of research materials, yet there is sufficient commonality to justify saying that these books represent only one slice of the totality of narrative studies. All four are published in Oxford's Explorations in Narrative Psychology series, edited by Mark Freeman, who contributes one of the most interesting chapters to the Life as Narrative anthology. There are further linkages between these volumes: Jens Brockmeier has a chapter in Life as Narrative, and William Randall writes that book's Afterword; 
Brockmeier and Lars-Christer Hydén have collaborated on previous edited books; and most notably, Life as Narrative comprises chapters that began as presentations at a conference jointly sponsored by the same centre that publishes this journal, of which Elizabeth McKim and William Randall are editors. I could add my own multiple collegial engagements with Brockmeier, Hydén, McKim, and Randall, but the reader gets the idea: this review itself is part of an entanglement of narratives, to play on Hydén's title.

Book reviewers are like storytellers: we fabricate a narrative while acknowledging more or less of what we ourselves have at stake in how we attempt to shape what readers feel they have at stake in the books being reviewed. My selections of what to single out from among these books reflect my own perspective, and in the final section of this review I will discuss how these books crystallized my understand of why I'm not a narrative psychologist, as much as I learn from the Oxford Narrative Psychology series. Interests overlap, boundaries are fuzzy, but differences can be articulated, with the hope of advancing dialogue.

Narrative is like the elephant in the fable of the five blind men, each grasping a different part of the beast and saying with certainty what sort of animal it is, based on that grasp. The moral of that fable, for me, is that the blind men's five stories all need each other; the truth of each depends on the alternative versions, which do not compete but rather complement each other. Among multiple stories, problems begin when one story claims representational privilege. The problem of writing about narrative is to make a case for one's own perspective without foreclosing other ways of understanding. All the authors in these books are notably respectful of the limits of their own work; they understand scholarship, like life, to be inherently collaborative.

\section{What Sort of Life with What Sorts of Stories?}

The late Jerome Bruner was a keynote speaker at the 2012 conference where most of the chapters in Life and Narrative were first presented, and Bruner is the most cited author in the book, followed by Roland Barthes and Paul Ricoeur. The volume is dedicated to him. Thus it's fitting to begin with one of the most usefully enigmatic lines from Bruner's chapter. Invoking Kenneth Burke's concept of Trouble-“a violation of the conventionally expected, an upsetting of what should be taken for granted" (p. 4)-Bruner writes: "Without Trouble there is no narrative, no story.... A story is an account of efforts to put things right" 
(p. 4). Read literally, Bruner is saying that a story describes how the characters, in actions now past, put right what was troubled. He was well aware that the telling of the story, in present time, is itself often an act of putting right a trouble in the relationship between the storyteller and her listeners. These two levels of a story being about putting right and storytelling as itself putting right are always entwined to some degree. When storytelling goes well, each level supports the other; but sometimes thing go badly, which is another variety of trouble.

Bruner's short chapter also does not have time to make explicit that what people count as putting right has itself been established by previous stories - at least in a narrative view of meaning and moral sense. A story being told now draws upon those earlier stories as its resource for what teller and listeners know as right, and to some degree, slight or significant, the present story proposes to modify that sense of rightness. Some stories reinforce an established sense of rightness, affirming its taken-for-grantedness, and other stories challenge established terms of rightness, aggressively proclaiming new possibilities.

Bruner's short quasi-definition of stories thus opens into multiple dimensions. We have actions in the story and actions of the storytelling, and on another dimension, rightness affirmed and rightness challenged. I propose that grid as a simple but useful device for understanding the interests of the writers of these four books. Most of these authors, on my reading, are more interested in acts of storytelling than in the action related in the stories. And most of these authors seem more concerned, at least in these publications, with how stories sustain a sense of rightness, rather than how stories challenge the dominant rightness. These generalizations about the books have exceptions, because there is a lot of material here. But my interest is in proposing a grid that allows readers to organize this material around what its core interests are.

In line with this interest in the storytelling itself and its effects, and with sustaining rightness established in previous stories, these books all show a preference for what has come to be called small stories. Although Alexandra Georgakopoulou's two chapters in Life and Narrative declare the most explicit interest in small stories, I find the most useful definitional statement to be proposed by Freeman: "Small stories are the rough, inchoate, in situ stories that comprise much of ongoing experience, and big stories are the more fully-formed, reflectiondriven stories that emerge after the chaotic dust of the moment has settled" (p. 23). I especially appreciate Freeman's “chaotic dust of the moment" phrasing. Another way of understanding small stories is to say 
that they lack a specific Trouble, in the Burke/Bruner sense. Thus there is no resolution to this trouble, and no evaluation of that resolution. What, then, do small stories do? Why tell them?

One answer is provided by Brockmeier in Beyond the Archive, where he usefully reviews the functions of language proposed by the linguist Roman Jacobson. The most distinctive contribution of this typology is the category Jacobson called the "phatic function," which includes everyday greetings like "Hi, how are you?" Such speech is not about content; the recipient of "How are you?" usually responds with a reciprocal greeting/question. It would interrupt the flow of conversation if either ever actually answered the other's question. What counts in phatic communication is establishing and confirming the connection between speaker and recipient of speech. Brockmeier gets at what is at stake when he writes: "The phatic function is the trace of the body in language. It makes sure that the storyteller is bodily present even if important dimensions of linguistic interaction (such as sound structures, syntax, and semantics) fail” (p. 214).

In small stories, important dimensions of storytelling are absent, including plot, characterization, description of scenes, temporal sequencing, and perhaps most significantly, any explicit evaluation of what is being told. These omissions can actually reinforce the value of small stories as phatic communication, because they presuppose that speaker and recipient already share such understandings. Telling a small story implies sufficient shared background understanding to make such a sketchy story comprehensible; such storytelling assumes an intimacy that big stories work to create. Thus, in small stories, it's the act of storytelling that counts, not the content of the minimal story that is told. Small-story telling is more useful at reaffirming existing understandings, because mounting a challenge requires a bigger story. At most, small stories can chip away at existing evaluative understandings, but few of the stories in these books are described as doing that. The reaffirmation function is most explicit in Hydén's research report, Entangled Narratives.

Among the chapters in Life and Narrative, James Phelan's contribution is a bit of an outlier; Phelan is among the literary narratologists in the book. He takes on one of the elephants in any room where narrative is discussed, which is the veracity/fictionality of stories; how does a story represent what actually happened in some then-andthere? Witness testimony in courtrooms represents one extreme of storytelling that is understood as directly representational of what happened. The side that calls the witness wants to minimize Freeman's 
"chaotic dust of the moment"; instead, the court-witness storyteller is presumed to have the clearest view and to be able to represent that view in transparent language. Medical stories, both patients' histories and stories between healthcare professionals, fall at this same end of the continuum. At the opposite end are fictions in the sense of fantasies, stories that are evidently counterfactual to reality, spun out of the storyteller's imagination. Social scientists, like judges and physicians, need stories collected in ethnography or told in interviews to be understandable as falling at the representational end of the continuum. But the epistemology of that continuum has been eroding - a process that animates all these books, in different ways - and social science is changing with respect to what stories it needs.

Phelan deconstructs this continuum of representational correspondence, and his argument has extensive implications for social science, for health research and practice, and for understanding narrative as a medium of everyday interaction. Stories, both their telling and their comprehension, depend on other stories, among which fictional stories are paramount. "Our everyday uses of language in nonfictional discourse," Phelan writes, "are shot through with fictionality" (p. 57). He then makes his point more explicit: "By fictionality, I mean uses of language that signal their reliance on inventions, as they depart from the realms of the actual, the factual, and the referential" (p. 57). His conclusion gets at how significant a reorientation he proposes: "Once we recognize just how pervasive fictionality is in nonfictional discourse, we can revise the view that the genre we call fiction depends on secondary uses of language existing in a realm cut off from the so-called real world and from real life" (57). Taking Phelan seriously, we can and should revise the view that there can be genres of nonfiction that offer representations of a realm that is exclusively real life cut off from imagination and invention-again, court testimonies, medical histories, and interview reports exemplify this assumption of fiction-free discourse.

Phelan does not move from these statements to a critique of health, psychology, and social science discourses, although he could have and someone should. His main concern turns to what he calls assessing the quality of experiences of fiction. I will skip to his statement that is less a conclusion than an opening: "I want to shift from talking about fiction and life to talking about reading fiction as part of life" (61). Whether a reader finds that statement threatening or enticing can be the hinge of a career. 
Life and Narrative moves to big stories in its final section, in which five scholars discuss two texts, both concerned with the World Trade Center attacks of September 11, 2001. One is Deborah Eisenberg's short story, "Twilight of the Superheroes," and the other is an eyewitness interview collected in Columbia University's Oral History Archives. Among these chapters, I found Brockmeier to be the most at home with the material. He moves from close reading of the two texts to a general conclusion for the volume as a whole, engaging the questions of narrative and self - is there a narrative identity, and if so, what? - that have been raised in most, if not all, chapters. Brockmeier makes three points that should be reiterated as touchstones for future work in narrative psychology.

First, Brockmeier understands small and big stories as mutually dependent on each other. He writes that "meaning-making is rarely exhausted in one act. It rather consists of many different and often fragmentary acts realized at different moments in time... in the heat of the moment...and then, afterward, what it was about and what it will be about" (p. 287). Extending this argument in my words, small stories of the moment are sifted, and some are eventually recollected in big, retrospective stories. These big stories can then be heard resonating in future small stories. Second, despite all the talk about how stories provide meaning, Brockmeier reminds us that narration always lacks: "It may not just be difficult to find a center, a clear endpoint, a telos of increasing understanding in events experienced as overwhelmingly complex; the point of possible comprehension may move even further ahead in the process of understanding itself" (p. 288). He then adds, even more provocatively: "Perhaps there is no goal at all and it is spreading tentatively in various directions, far from any "fusion of horizons" ( $\mathrm{p}$. 288). Third and most simply, Brockmeier reminds us: "There is no guarantee that our acts of meaning construction will succeed" (p. 289). In a volume that takes significant inspiration from Jerome Bruner's 1990 classic Acts of Meaning, that last statement is arresting. Is it pressing Brockmeier's argument too far to propose that stories can be acts of making life liveable in the absence, at least the perpetual abeyance, of meaning?

\section{Narrative Enactments of Mutual Devotion}

Two contemporary figures representing this absence of meaning are, at the societal level, the terrorist attack that the final section of Life 
and Narrative focuses on, and at the individual level, dementia as loss of narrative capacity. Lars-Christer Hydén contests this imagination of dementia. He has for several years focused on narrative co-constructions achieved by couples in which one partner suffers from dementia. On my simple grid of authorial interests, Hydén is exclusively interested in couples' acts of telling the smallest of stories that sustain their relationship and reaffirm the personhood of the person with dementia.

Entangled Narratives is the most research-focused book among these four, based on interviews that Hydén's students have been conducting for a number of years. The interviewers talked to elderly married couples, asking simple questions designed to elicit stories. "How did you meet?" is one such question, and several interview transcriptions show the well spouse guiding the ill spouse through the construction of a narrative (for example, p. 95). Well spouses practice what Hydén calls scaffolding, taking that term from Bruner, although it's used by others as well. Hydén describes scaffolding as the "redistribution of activities and responsibilities in storytelling" (p. 107). In conversational practice, the well spouse prompts the ill partner to express what becomes the next building block in the developing narrative, often elaborating the minimal responses (see p. 135). "The storytelling can continue as the participants incrementally add new parts to their common ground," Hydén writes ( $p$. 146). The well spouse does the work of keeping up the other's engagement, but that engagement is real, however minimal.

What is jointly produced is a very small story that does critical work in a situation where one person's capacity for engagement requires reaffirmation. "This is part of making the storytelling not just the delivery of a story-text but a collaborative activity. Participants not only respond to each other, but also share a commitment to a common activity...displaying their mutual engagement and their present understanding of what they are doing together" (p. 146). In Bruner's terms, with which this review began, the co-produced telling, without being much of a story, puts right a relationship that is troubled by dementia. The story-text, as Hydén calls it, is a snapshot of the past relationship - a moment that the present storytelling reaffirms in its significance. Because reaffirmation depends little on what specific story is told, Hydén has minimal interest in defining a story (see p. 40). His interest is in what he calls the storytelling system: "It is necessary to consider the storytelling activity as a kind of system that is organized around a number of cortical resources, from specialized parts of the brain, 
to associative areas in the brain, as well as cultural tools and artifacts, to other persons' resources" (p. 58).

Hydén seeks to instantiate a new professional and cultural narrative of dementia, moving beyond studies of individual deterioration and looking instead at "how people tell stories together and in what ways the presence of dementia alters how people collaborate" (p. 117). In the language of narrative therapy (Frank, 2018), Hydén's phrasing externalizes dementia, reimagining it not as an internal state that defines a person, but rather as an unwanted guest whose presence couples have to accommodate. Hydén's work shows how married couples can learn to live with early stages of dementia, using collaborative strategies. Those strategies are not exclusively storytelling, but storytelling is a crucial venue for learning and practicing these strategies.

How speakers elaborate each other's "resources" (p. 58) is probably the main contribution of Hydén's book, and the point of his title. Hydén, as we will see later with Brockmeier, emphasizes the messiness of what happens. "The stories, the storyteller, and the listeners become entangled in broken stories: beginnings and endings are twisted together, interwoven with repetitions of the same event, resulting in shared states of narrative perplexity" (p. 4; see also pp. 49, 113).

The larger project is to propose a radically interpersonal conceptualization of the self, something all these books do, but Hydén specifies it - or maybe I just like his ideas best. On his account, the self is constantly being co-produced in interaction. It "is not to be found 'inside' the individual's skull.... Rather, the sense of self [n.b., sense of] is connected to various practices, in particular linguistic ones, that persons use in everyday interaction in order to present and negotiate various aspects of themselves as persons" (p. 114). Hydén cites the sociologist Erving Goffman several times, and I hear a good deal of Goffman behind this interactive conception of the self and the understanding of storytelling. I mean it as the highest praise that Hydén has produced a distinctly Goffmanesque understanding of dementia. But Goffman would have stopped at the level of collaborative practices and their cultural resources. Hydén's interests include the distinctly moral dimension of lives lived in entangled narratives.

What is most moving to me as I read Hydén is his continuing display of couples' mutual commitment to their relationship. The "joint stories" that couples co-construct, albeit with one spouse doing the scaffolding work that engages the other, "portray the spouses as belonging together, as sharing experiences and values, as being more than 
just two individual persons" (p. 180). Being more than just two individuals "entails certain moral obligations that are part of the joint activity as such. It could further be argued that the mutual commitment of the participants is also based on their long-standing relationship and their attempts to sustain this relationship in the face of the progressing disease" (pp. 139-140). In my gloss of these passages, each person's moral commitment to the other makes possible not only the other's personhood (see Lindemann, 2014, another collaborator of Hydén's), but also their own personhood as well. The other's presence - that person's face in the term used by the philosopher Emmanuel Levinas's terms (Frank, 2004)enables the moral commitment, that acting on that commitment substantiates a claim to one's own moral standing. I would call this a radically Pragmatist view in which morality matters less than living moral life. People's commitment is less to principles than to other persons, less to nameable values than to participation in practices that enact-and must perpetually reenact - what counts as value. I don't think I am pushing Hydén's argument too far, and if I am, then collegial life depends on each's ability to respond to others.

Hydén is explicit about the limitations of how his interview materials depict living with dementia. His book "is about persons with early to mid-phase Alzheimer's disease," and "late stage" situations are beyond his scope (p. 23). For a glimpse of what such late-stage disease can involve, Freeman's depiction of his mother's dementia, presented in his chapter in Life and Narrative, offers a compelling counterpoint and complement to Hydén's research. Hydén is selective, favouring "examples about possibilities, such as what persons with dementia can actually do, rather than using examples illustrating the loss of abilities" (p. 23; see also p. 138). Entangled Narratives takes a position; it advocates in its own way. But Hydén is never naive about the difficulties that confront those living with dementia and those struggling to support loved ones. More than occasionally, he reminds readers that joint storytelling can fail and it has risks of its own (see pp. 121-122).

The stories that spouses tell are about their shared past. These stories are acts of memory, with memory understood not as what is stored within any one person, but rather as a collaborative work of constructing a narrative or fragment as a response to the present situation. The situation calls forth the memory; demands of the situation shape what is remembered, and this newly shaped "memory" then informs the situation. Most important for Hydén, memory is thus distributed as a joint activity (p. 138; see also pp. 125, 168, \& 198). The theoretical details of this 
reconceptualization of memory are developed in the work of Hydén's occasional collaborator, Jens Brockmeier.

\section{The Three-Legged Stool of Self, Memory, and Storytelling}

Brockmeier's book stands out as one of those rare works of scholarship that deserves to be called magisterial. Brockmeier asks big questions - the nature of the self, of memory, of how autobiographical narration works and what it effects - and he demonstrates expertise in an array of literatures from neuroscience to literary fiction. He has published extensively, including multiple collaborations, yet I believe this is his first single-authored book in English. As such, it is a throwback to an academic age when scholars delayed publishing the work that defined their career contributions. Brockmeier weaves an extraordinary web, and I fear this review will do the least justice to his achievement.

What Brockmeier says about memory can be well introduced by a quotation from the late Jenny Diski, the British essayist and short story writer:

Memory does not have a particular location in the brain, as was once thought, but resides in discrete packets dotted all over the place. Or it doesn't reside anywhere, except in remembering itself, when the memory is created from the bits of experience stored around the brain. Memory is continually created, a story told and retold, using jigsaw pieces of experience. (Quoted in Schwartz, 2017)

Diski uses the verb "created" twice. Memories are not recalled; they are created, in the form of stories that are told and retold. Experience is jigsaw pieces used as the material for memory-creations. These memorycreations are not out-of-nothing; they are not acts of pure imagination (if there are such acts, which I doubt). But, crucially, the principal resource for the present retelling of a memory is not what originally happened. Rather, the present memory-creation depends upon the most recent retelling, and so on, all the way back.

Extending Diski's reflection, the self is that which keeps on telling and retelling, putting the pieces together in slightly different patterns and occasionally generating what seems like a new pattern. The term narrative self is less useful than imagining a perpetually narrating self- 
until the narrating stops, which is how Freeman describes his mother's dementia in his chapter in Life and Narrative.

In Brockmeier's central metaphor, there is no archive in which memories are stored, awaiting recall. Here are two passages in which Brockmeier offers his extended, scholarly version of what I understand Diski to be saying. I hope these passages are not unfair as representations of Brockmeier's writing style. The first passage follows a quotation from Plato, who described memory through the metaphor of an impression made in wax; the argument segues to Freud:

Drawing on the heritage of a long tradition of thinking about memory, Freud adapted Plato's wax tablet to his own theory in which the idea of memory as an (unconscious) writing was pivotal. What this idea missed, however, as Derrida...criticized in his analysis of Freud's conception of remembering and forgetting, was the multilayered, fleeting, and meandering dimension of all three: memory, metaphor, and writing - in a word, their qualities as a palimpsest. It appears that Derrida had a point, because it is exactly this palimpsestic quality of remembering and forgetting in which many recent authors, artists, and cultural memory theorists - in fact, even neurobiologists of memory [citation in original] - have been interested. (p. 69)

Among those recent authors is Jenny Diski, and Brockmeier's frequent turns to non-academic authors suggest he would be comfortable with my beginning discussion of his book by quoting Diski. Brockmeier, like Freud, recognizes that scholars are often catching up to poets, or in Brockmeier's case, to novelists. One chapter in Beyond the Archive is devoted to explication of a passage from Ian McEwan's novel Saturday, and another chapter discusses the genre-defying book Austerlitz by W.G. Sebald. These texts are the original data supporting Brockmeier's argument. As to what that argument is, here is a second quotation from Brockmeier:

One feature of the picture of narrative identity that emerges in the work of Lindemann Nelson, Ritivoi, and other researchers [multiple citations] is that it shows no contours of a coherent and continuous self but quite the contrary: an unstable scenario of tensions, contradictions, struggle, and negotiations-a "messy self," as it has been experienced and described by many writers 
and literary scholars since the early 20th century [further citation].... Despite my longstanding interest in the various dimensions and aspects involved in the dynamics of narrative identity, it has taken me some time to realize that what I tried to make sense of was, however, not the relationship between "identity" and "memory" but the autobiographical process and its interpretive and creative interplay with people's narrative constructions of themselves. This may seem an insignificant conceptual shift, yet it gives this book an orientation quite different from other approaches...centered on memory and identity. (p. 180)

At the risk of belabouring Brockmeier's conceptual shift, he is rejecting identity and memory as entities with any thing-like essence, much less location. Instead, identity and memory are dynamic practices of telling and retelling "people's narrative constructions of themselves" ( $p$. 180). "Autobiographical process" is, on my reading, both a cultural resource-people learn how to tell stories about their lives-and a constant innovation, as people adapt that resource. Crucially, whatever is is what emerges in the telling.

I agree with Brockmeier throughout, but where I most agree is when he writes: "We start with a story, or more precisely, with a number of stories, or fragments or traces of stories because we were born into, grow up, and live in the midst of a world of narratives that...for the most part are not our own" (p. 181, emphasis added). Brockmeier then gets to his own usage of the word that is crucial for Hydén, "entangled." "The stories we tell mingle in countless ways with other stories, which they take up, continue, imitate, vary, criticize, repudiate, in serious and playful ways. As a consequence, we and our lives are more and more verstrickt, entangled, in stories and the storyworlds to which they belong" (p. 181).

Brockmeier argues that the entanglement of memory and narrative in an autobiographical process does not reflect a life that has some kind of free-standing existence. Rather, continual engagement in autobiographical process is what gives me a claim to having a life of my own, and the ongoing reasserting of that claim is called identity. Returning to the earlier quotations, this identity or self is messy; it is "multilayered, fleeting, and meandering" (p. 69).

What Brockmeier calls the palimpsestic quality is the process of constantly overwriting what was written: "Each act of remembering an experience is itself a new experience, which, in the very act, subtly 
transforms the memory of the 'old' experience. In this way, we might add new emotional values, new beliefs, and even new knowledge to our memory of that face, fusing all of it with what we all the same consider an authentic and original memory" (p. 57). The latter point about what we consider "original" is important. We humans carry on without knowing ourselves as engaging in this palimpsestic overwriting. We can tolerate reading fictions that depict that overwriting, but most people would find it untenable to live with such a self-understanding; we literally could not hold on. Moreover, institutions require that our acts of memory correspond to original occurrences.

Understanding humans as living in a state of strategic ignorance about their memories might place Brockmeier, who most favours the word hermeneutics, in the camp of hermeneutics of suspicion, but I think not. His work can be usefully called postmodern, a term he uses, because his version of hermeneutics posits no master interpreter who can produce a privileged version of any particular memory or of how to remember. That takes us to Brockmeier's choices of Ian McEwan and W. G. Sebald as each deserving his own chapter.

McEwan and Sebald exemplify writers whose creative excellence is their craft at catching in prose a moment of the autobiographical process as it is in process, in full flight. As Brockmeier analyzes McEwan's (2005) Saturday and Sebald's (2001) Austerlitz, neither narrative tells a story in Bruner's sense of starting with a specific Trouble that is eventually put right. If anything, in both books the narrative goes in the opposite direction, as matters become more troubled. Both books are about protagonists who exemplify a condition that the reader recognizes him or herself sharing: living with a trouble that cannot be fully specified and so defies being put right. At least that's my almost certainly over-simplifying gloss of books that are all about the impossibility of simplifying glosses. Brockmeier turns to these artists to get outside of the discourses of psychology, neurobiology, and philosophy that require, as a condition of participation in the discourse, ending with a definitive gesture of putting right.

For Brockmeier, there are scarcely even small stories. The most extended passage he quotes from Saturday (p. 133) is a stream-ofconsciousness of the protagonist early one morning, half-awake, planning what he will buy for dinner, using the bathroom, and eventually humming a tune while he makes coffee. It is a succession of fragments. In Diski's metaphor, the passage shows us pieces of the jigsaw puzzle lying dumped on a table, awaiting assembly into a recognizable picture. That is 
Brockmeier's psychological interest: how, out of such fragments, does the protagonist claim a self? As I read Brockmeier, he studies what happens antecedent to storytelling; what makes storytelling possible, later. That's why his chosen examples are narrations struggling to become stories, but never achieving that, probably ever.

Because Brockmeier's argument is about the impossibility of forms of closure, there is no self-evident ending to his magisterial book. Consistent with his style throughout, his conclusion brings together the German installation artist Anselm Kiefer, the philosophers Richard Rorty and Ian Hacking, and again Bruner. It's a tour de force intellectual mashup, but I lose Brockmeier himself in the thicket of his sources. Perhaps the conclusion is better read not as proposing a theory, but rather as reenacting Brockmeier's understanding of the self constantly getting lost in fragments that never quite fit together. Now that Brockmeier has written his big book, I hope he will write a shorter one, perhaps more about his own memories. For a model of what such a book might look like, he might read William Randall.

\section{Deconstructing the Big and Small Story Distinction}

Randall describes his book as "a memoir of my life in narrative" (p. ix), then invoking the descriptive term, autoethnography (p. ix). If we are trading in neologisms, which Randall's book is happily free of, I propose calling it an autonarratology, meaning that Randall uses his own life stories to study stories and storytelling. His work is the most evenly balanced in its attention to big stories and small stories. The big stories are about turning points in Randall's life; in these stories, something happens, and life at the end is substantially changed from how matters stood at the beginning. One such story is how he, the child of a lower income family in the rural Maritimes, got into Harvard. It's a proper tale, taking several pages (pp. 58-66) to tell, with dramatic tensions, fully rounded characters, and suspense.

Randall's small stories are those told as the principal medium of sociability in the small-town coffee shop where he writes his book. People in the coffee shop understand that setting as giving them what early conversation analysis called a ticket: rights to speak to strangers in public places. That Randall is engaged in writing, with a pile of books around him, actually seems to make him more available as a participant in passing conversations. A refrain of his book is strangers asking him what he's working on. Those inquiries and the story exchanges that follow set 
the book's tone. Hydén writes with the echoes of couples' interviews in his head; Brockmeier writes within his immense inner library that reaches from Plato to contemporary neuroscience. Randall writes as he constantly describes his project to friendly people in a lower-end chain coffee shop who think that anybody there can be recruited for casual chatter.

"They have little to say," Randall writes about those in his coffee shop, "or at least little by way of audience who's willing to listen, and what they say is often tentatively expressed, as if they're uncertain it makes any sense" (p. 34). Randall loves these people, in his own way, and his book exemplifies his practice of "narrative care" (p. 35). "Sometimes, I fancy myself the last soul whom they talk to before quietly concluding their lives. You never know. The little chat we have today may seed their hearts with happier, more hopeful versions of themselves" (p. 35). That's narrative care.

What I like best about Randall's book is that he allows the stories - a lot of stories, big and small - to carry the argument. More than anyone I read on narrative, including Bruner, Randall convinces me that he lives with stories as his constant companions; he trusts stories. And Randall makes explicit what is, for me, possibly the crucial question: "Why is it we've retained the stories that we have and not other ones instead?" (p. 57). This question sets Randall's terms of identity. Who we are is defined by those selective retentions of some stories and not others; that selection, which is always a process, never finalized, is momentous in the kind of life we lead. And for Randall as for me, the principle(s) of selection is pretty much a mystery. We can give this process different names-I call it narrative habitus (Frank, 2010) - but these names call attention to what's happening without explaining it. The point may be that there is no explanation for why some stories stick to some people, and other stories are so readily forgotten — but that process defines each of us.

Reconsider my earlier quotation from Brockmeier, with my added emphasis: "We start with a story" (p. 181). I'm not sure whether Brockmeier takes that emphasis as seriously as I do or as I believe Randall does. Stories are ground zero; they precede any explanation. They themselves are as much explanation as we get. But it's even shiftier than that. Randall recalls the voice-over narration of an otherwise forgotten movie saying, "This story has many beginnings" (p. 59, emphasis omitted). He knows that is true of his own life stories. Because any story can always be told with a different beginning, it can always be told differently and will have different effects. The mystery is not only which stories we retain, but also how we tell the same story on different 
occasions. Randall puts it well: "All we have are versions of versions of some supposed original that is all but lost in the mists of distant time" ( $p$. $163)$.

That last statement could be a gloss on Brockmeier's theory of memory, but it actually occurs at the end of Randall's insightful discussion of religion. Before his academic career, he was a parish minister, like his father before him. Religious life hinges on stories, from sacred stories to parish gossip. But faith communities are a venue where the dangers of stories can be most evident. Randall expresses the central danger, which is one aspect of what the great narratologist Mikhail Bakhtin (1984) would call monologism: “One story comes to prey upon others, holding central to its version of the world the view that other versions are, by definition, false" (p. 162). I am remiss in quoting that line out of context, because its force as a statement depends on the lengthy sequence of big and small stories through which Randall earns what he says. But the statement exemplifies the genuine wisdom of this book. Randall is the lightest among these authors in terms of his reliance on academic sources; he is most strategic in whom he quotes, to what effect. That opens the text to his own voice, and the richness of his accumulated experiences and reflections.

It comes back to the coffee shop and Randall writing his book in conditions of constant availability to others. Randall makes me wonder if my own biggest mistake hasn't been working in own study, an enclosed space, arranged to my taste. Such working conditions induce monological thinking, while my writing proclaims dialogue as a principle. Randall practises dialogue as an embodied condition of putting himself in a public space. His writing not only deconstructs any division between big and small stories, showing how one type flows into the other, with each type making the other possible. He also deconstructs the more damaging divisions between academic life and what his title calls "ordinary life." I admire the scholarship exemplified by both Brockmeier's range of source material and Hydén's careful research; I believe in the need for that scholarship. But few colleagues could write a book connecting the scholarly and the ordinary with Randall's skill and, truly, his grace.

\section{Why I Am Not a Narrative Psychologist}

I began by pointing out that these books are all published in Oxford's Explorations in Narrative Psychology series. More than that fact of common publication, they have a certain family resemblance in their 
presuppositions, foci of interest, method of argument, and what counts as a conclusion. Wittgenstein coined the term family resemblance to mark what can be recognized as shared in common, but admitting that this commonality defies being articulated. Narrative psychology has fuzzy boundaries and is constantly shifting as new work comes along. But it is recognizable in these books. I can describe its family resemblance best by suggesting what it omits as beyond its interest.

That the terrain of narrative psychology is not my home ground is marked by these books' lack of attention to my own writing about stories and storytelling, beyond my work focused on illness narratives. In all these pages, there are two passing references to my major work on narrative (Frank, 2010). I don't take that personally, because there are also no references to my most significant resources for thinking about stories and storytelling. No references to the sociologist Pierre Bourdieu (2000), whose writing on disposition is crucial to how I address the question of how we select which stories we pay attention to and which we readily ignore or forget. No references to anthropologists like Julie Cruickshank (1998), reflecting these books' lack of interest in storytelling among Indigenous peoples-who organize their lives most selfconsciously around stories - or in the folkloric and mythic foundations of storytelling. No references to Bruno Latour (2005), whose actor-network theory is my basis for thinking about how stories work as actors in networked relations, both with other stories and with their human tellers. These books show little interest in stories as what Latour calls mediators of affiliation among persons, changing the persons who relate to each other through storytelling. Even Bakhtin gets comparatively few citations, most of which are passing references, with no interest in his understanding of stories as a distinctive speech genre (Bakhtin, 1986). Disinterest in my work thus reflects a broader disinterest in a way of thinking about stories that can be vaguely distinguished as nonpsychological. There is a different way of thinking about stories that remains outside these books, as extensive as their interests and approaches are.

One way into this difference is to note a quotation that occurs twice in these books, and then to ask how far the authors take the implications of what it says. Brockmeier writes: "If adventures happen only to people who know how to tell them, as Henry James famously remarked..." (p. 172). Catherine Karen Roy, in her chapter in Life and Narrative, quotes Jerome Bruner, who recalls James somewhat differently, writing: "Stories happen to people who know how to tell 
them" (p. 178). For me, the seriousness of James's observation is expressed in Brockmeier's statement that I have already quoted twice, giving it an added emphasis: "We start with a story" (p. 181). Stories precede: they precede selves and their memories of what they know as their experiences. That means, for me, that stories have a spooky ontology, a provisional existence as things outside of consciousness, waiting to shape nascent consciousness and then be repaid when that consciousness perpetuates the stories' lives by retelling them.

For me, James is saying that the human capacity for a reflective sense of "having" any type of experience - adventures, being in love, suffering tragic loss, religious belief — depends on being able to tell that kind of story. Experience depends on having learned, from other stories, how to tell that kind of story. Thus experience is, at its origin, narrative. Stories are what phenomenologists call always-already there. And then, subsequently, experiences_adventure, love, suffering, gaining or losing faith-happens and is remembered in the autobiographical narrations that shift as Brockmeier describes, and that are distributed between the self and its others, as Hydén describes.

What interests narrative psychology is most visible when Brockmeier, whose expertise goes far beyond psychology but who thinks like a deeply phenomenological psychologist, does his most extended original analysis of the narrational fragment from McEwan's (2005) Saturday. He does not examine what he otherwise calls attention to, as quoted earlier: how we humans are entangled in stories (p. 181). He does not ask what stories are in this protagonist's consciousness. Brockmeier does not analyze how these stories, in his well-chosen words, "take up, continue, imitate, vary, criticize, repudiate [other stories], in serious and playful ways" (p. 181, quoted earlier). Brockmeier's exemplary moments of consciousness are not, or not yet, what I would call storytelling moments. His interest has every claim on our attention. I agree that McEwan's representation of these moments is true to how life is lived, and much of life is lived in such moments. Humans do not continuously think in and with stories; stories are a distinct speech genre. But narrative psychology pays a price for dissolving stories into smaller and smaller fragments until ultimately any thought seems to count as a story. The price is that the distinctiveness of the speech genre of story can get lost. Plus, the narrative psychology approach, of which I am holding up Brockmeier as the most sophisticated practitioner, does not take Henry James's statement about adventures as literally as I do. 
To me, neither Diski's metaphor of the jigsaw puzzle nor James's aphorism seems sufficient as it stands. With respect to Diski, the issue is not only consciousness assembling the jigsaw pieces into stories. What's involved is also stories creating a kind of magnetic field in which the pieces are attracted to form particular patterns known as stories. As Brockmeier says, and I added emphasis, these stories are "not our own" (p. 181, quoted earlier). To make the pieces fit the available stories, we cut bits off some pieces and add bits to others; if memory is putting together a jigsaw puzzle, then we routinely cheat. But it's cheating only if the goal is fidelity of representation to some original. If there is no original, then there's no cheating. But I would not go so far as to say there is no original. Happenings happen. Moral evaluation of trimming and augmenting the jigsaw pieces as cheating depends on its effects-who benefits and who pay what price. The inevitability of narrative shaping does not nullify the moral responsibility of telling a tale, including our own memories. Rather, the inevitability of narrative shaping makes remembering a moral action.

With respect to James saying that adventures happen only to people who know how to tell them, that statement needs to be augmented by being placed in a communal context. To have adventures, people have to live in communities that teach how to tell those stories and that value what such stories tell. That statement still lacks the full significance of Cruikshank's (1998) title, The Social Life of Stories. Stories live in communities that retell them, and communities define their boundaries by what stories they tell and how they understand the force of those storieswhat the stories call upon people to do, if they are to call themselves members of those communities. In Latour's (2005) terms, stories reassemble those communities; that's the work of stories, their distinctive agency. Thus my elaboration of James: people feel called to have adventures, if they share membership in communities that affirmatively evaluate adventure stories. A non-psychological interest in narrative is in how group boundaries are created and sustained because affiliations of people know different stories, and when stories about the same events are told on different sides of a boundary between groups, those stories are understood differently on each side (Cruickshank, 1998, especially chapter 4, discussed in Frank, 2010, pp. 78-81).

I wrote earlier that humans are not so much narrative selves as they are narrating selves, whose selfhood continues as long as the narrating does. That's what is at stake for the couples whom Hydén studies, as the well spouse sustains the fading narrative participation of 
the ill spouse. We humans do that work of sustaining narrative participation not only for each other in immediate relationships. What Indigenous storytellers may understand best is that any individual's narrating is only one small pulsing within a far more extended, encompassing narration. Each part does its part; Randall recognizes this by honouring the smallest coffee-shop story. Small stories are forceful because they resonate big stories, and big stories retain their tellable interest-their force-because small stories keep us prepared for moments when big stories come along. Most stories mutually reassure tellers and listeners that things are pretty much the same. But then some stories - exemplified by the 9/11 stories discussed in the final section of Life and Narrative - struggle to find a narrative adequate to changes that are threatening because what's happening is undeniable but no narrative form provides for telling a story. These books seem most provocative when they reach the moment that inverts Bruner's description of a story: when trouble is happening, but it cannot be put right.

\section{References}

Bakhtin, M. (1984). The problems of Dostoevsky's poetics. Minneapolis, MN: University of Minnesota Press.

Bakhtin, M. (1986). Speech genre and other late essays. Austin, TX: University of Texas Press.

Bourdieu, P. (2000). Pascalian meditations. Stanford, CA: Stanford University Press.

Cruikshank, J. (1998). The social life of stories. Lincoln, NE: University of Nebraska Press.

Frank, A. W. (2004). The renewal of generosity: Illness, medicine, and how to live. Chicago, IL: University of Chicago Press.

Frank, A. W. (2010). Letting stories breathe: A socio-narratology. Chicago, IL: University of Chicago Press.

Frank, A. W. (2018). What is narrative therapy and how can it help health humanities? Journal of Medical Humanities, 39(4), 553-563.

Latour, B. (2005). Reassembling the social: An introduction to actor-network-theory. New York, NY: Oxford University Press.

Lindemann, H. (2014). Holding and letting go: The social practice of personal identities. New York, NY: Oxford University Press.

McEwan, I. (2005). Saturday. London, England: Jonathan Cape.

Schwartz, M. (2017, December 7). Writing on thin ice: Review of Jenny Diski, The vanishing Princess. New York Review of Books, 17-18.

Sebald, W. G. (2001). Austerlitz. London, England: Hamish Hamilton.

Arthur W. Frank, PhD, is Professor Emeritus of Sociology at the University of Calgary, professor at VID Specialized University, Bergen, Norway, and core faculty at the Center for Narrative Practice in Boston. He is the author of a 
memoir of critical illness, At the Will of the Body (1991; new edition, 2002); a study of first-person illness narratives, The Wounded Storyteller (1995; expanded edition, 2013); a book on care as dialogue, The Renewal of Generosity: Illness, Medicine and How to Live (2004); and most recently, a book on how stories affect our lives, Letting Stories Breathe: A Socionarratology (2010). Dr. Frank is an elected Fellow of The Hastings Center and a Fellow of the Royal Society of Canada. He was the 2008 recipient of the Abbyann Lynch Medal for Bioethics, awarded by the Royal Society of Canada, and the 2016 recipient of a Lifetime Achievement Award from the Canadian Bioethics Society. 